\title{
A Cost Effective Desalination Plant Using a Solar Chimney with Recycled Aluminum Can Collector
}

\author{
Singuru Rajesh ${ }^{1}$ and Ravipati Bapaiah Choudary ${ }^{2}$ \\ ${ }^{1}$ Machine Design, Mechanical Department, Vignan's University, Guntur, Andhra Pradesh 522213, India \\ ${ }^{2}$ Mechanical Department, Sasi Institute of Technology and Engineering, Tadepalligudem, Andhra Pradesh 534101, India \\ Correspondence should be addressed to Singuru Rajesh; rajeshsinguru008@gmail.com
}

Received 23 March 2016; Accepted 11 May 2016

Academic Editor: Koray Ulgen

Copyright (c) 2016 S. Rajesh and R. B. Choudary. This is an open access article distributed under the Creative Commons Attribution License, which permits unrestricted use, distribution, and reproduction in any medium, provided the original work is properly cited.

\begin{abstract}
The main objective of the work was to use solar energy for desalination of water. A solar chimney desalination system, which includes the solar chimney, solar collector, evaporation system, and passive condenser, was designed and built. The air enters into collector and gets heated and released at the bottom of chimney. Due to draught effect dry air goes upward. The air is humidified by spraying salt water into the hot air stream using a mistifier at the middle of chimney. Then, the partial vapours contained in the air are condensed to give desalinated water. The performance of the integrated system including power and potable water production was estimated and the results were discussed. With a $3.4 \mathrm{~m}$ height setup, experimental test rig was capable of evaporating $3.77 \mathrm{~L}$ water daily condensing $2.3 \mathrm{~L}$ water. It is compact in nature as it is easy to assemble and dissemble. It can be used for purifying rain water in summer under rain water harvesting. Because of using country wood, recycled Al cans, and GI sheet in fabrication, it is lower in cost.
\end{abstract}

\section{Introduction}

Energy is the backbone of technological and economic development. Our energy requirements have increased in the years following the industrial revolution. This rapid increase in use of energy has created an imbalance between demand and supply. If this growing world energy demand is to be met with fossil fuels, they will be no more available for producing the energy after a few years. It is the need of today's world to concentrate on renewable energy sources to satisfy the demand and conserve our finite natural resources for the generations to come.

Khan [1] explains basic concepts of alternative energy related to issue of sustainability and pollution reduction. In reality alternative energy refers to any form of energy other than that derived via fossil fuel combustion. Various forms of alternative energy sources are solar, wind, biogas/biomass, tidal energy, geothermal energy, fuel cell, hydrogen energy, small hydropower, and so forth. Solution to long-term energy problems will come only through research and development in the field of alternative energy sources. There are many benefits of alternate sources of energy such as sustainability, ecofriendly environment, human health, and enhanced income.
Human body needs three requisites for its smooth functioning-oxygen, water, and food. First requirement to live is oxygen since one cannot survive more than a few minutes without taking oxygen. Water has been ranked as second only to oxygen as essential for life. The average adult body consists of 55 to $75 \%$ water. Water available on earth is about $79 \%$. Out of this $97 \%$ is sea water and rest is fresh water (Figure 1). Drinking water scarcity is increasing day by day (Figure 2). 3\% fresh water resources are not enough for the world. Safe drinking water could be defined as water that which can be used as drinking water for humans without causing them any harm, either short term or long term Rajesh and Suresh [2]. A lot of research has gone into finding the contaminant impurities in water that are harmful to humans.

One of the best ways to get pure water is by desalinating sea water or brackish water. Desalination is a process, which is used to remove dissolved minerals in feed water sources, such as seawater or nonpotable water for getting pure water. The safest and most effective water purifier in the market today works on reverse osmosis principle. But it is high in cost. It is proposed to use a solar chimney integrated with a recycled aluminium can solar collector to produce desalinated water. 

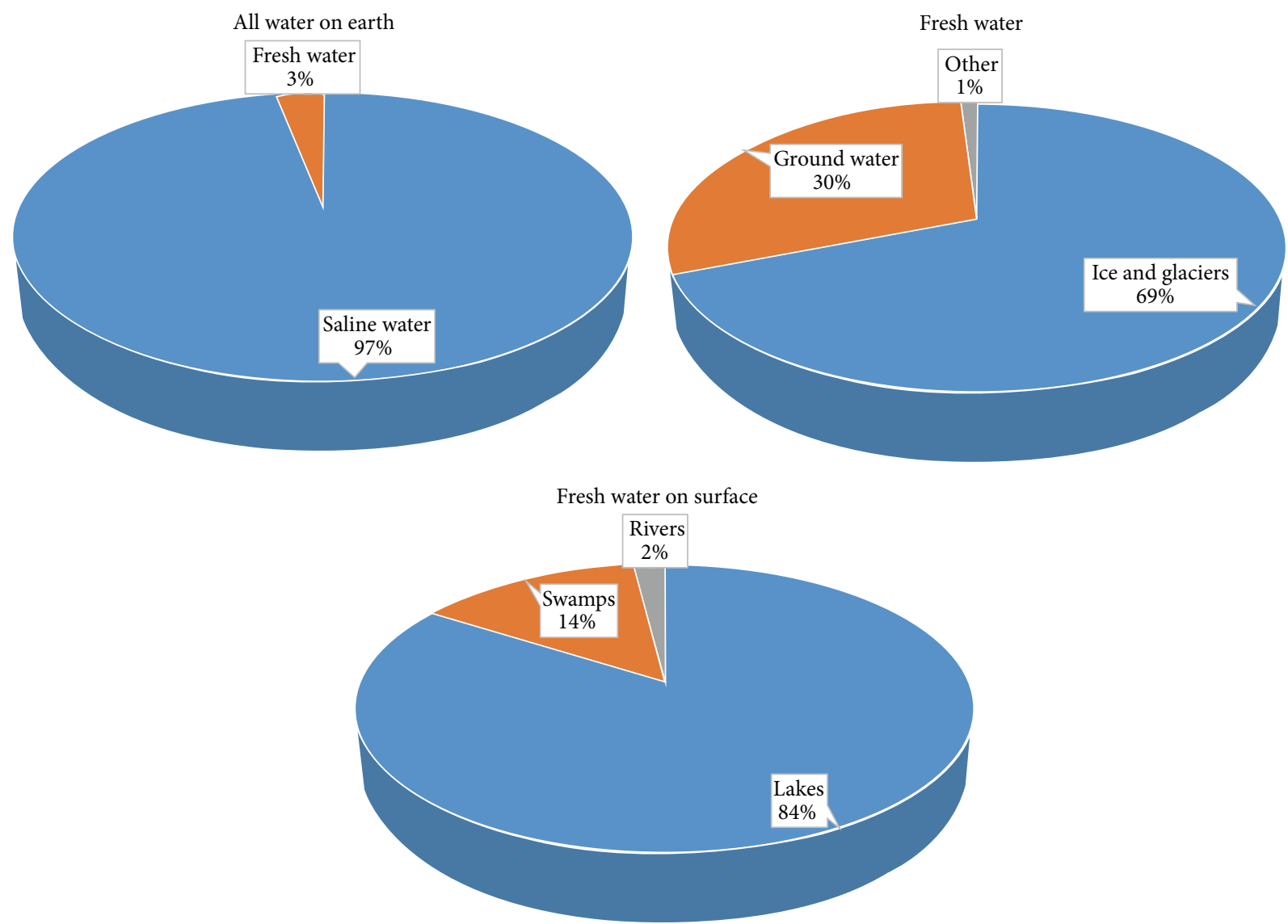

Figure 1: Types of water available on earth (courtesy: Pacific Islands Applied Geoscience Commission), http://www.pacificwater.org/pages .cfm/water-services/water-demand-management/water-distribution.

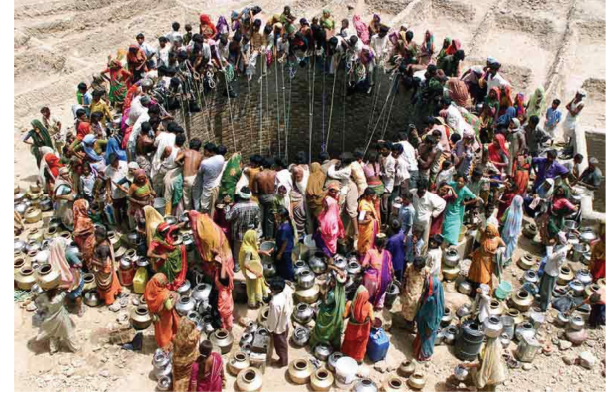

FIGURE 2: Water scarcity in villages (courtesy: Google images).

Two points considered to achieve are reduction in cost of equipment and ease of producing desalinated water.

\section{Literature Review}

Commercial desalination techniques have been heavily dependent on the use of electrical energy as the main source of energy. Consequently, with the high dependency on electrical energy, desalination processes also contribute to the increase in the production of greenhouse gasses emitted from the production of electrical energy.
2.1. Solar Desalination Methods. Solar desalination is a method which utilizes solar radiation to produce desalinated water. Based on this method different solar desalination plants are developed. This method is mainly classified into two types: (a) direct method and (b) indirect method.

In direct method, a solar collector is coupled with a distilling mechanism and the process is carried out in one simple cycle. Solar stills (Figure 3) of this type are employed in many small desalination and distillation plants. Water production by direct method solar distillation is proportional to the area of the solar surface and incidence angle. According to Pastohr et al. [3] solar productivity of still is low and occupies huge space. Indirect solar desalination consists of either photovoltaic or fluid based collectors. Production by indirect method is dependent on the thermal efficiency of the plant and the cost per unit produced is generally reduced by an increase in scale. Many different plant arrangements have been theoretically analysed, experimentally tested, and in some cases installed.

2.2. Solar Chimney Desalination System. According to Haaf [4], Solar Chimney Power Generation System was presented by a German Professor Schlarich in 1978. A pilot solar chimney power plant was constructed at Manzanares, Spain, in 1981. Since then, more and more researchers have 


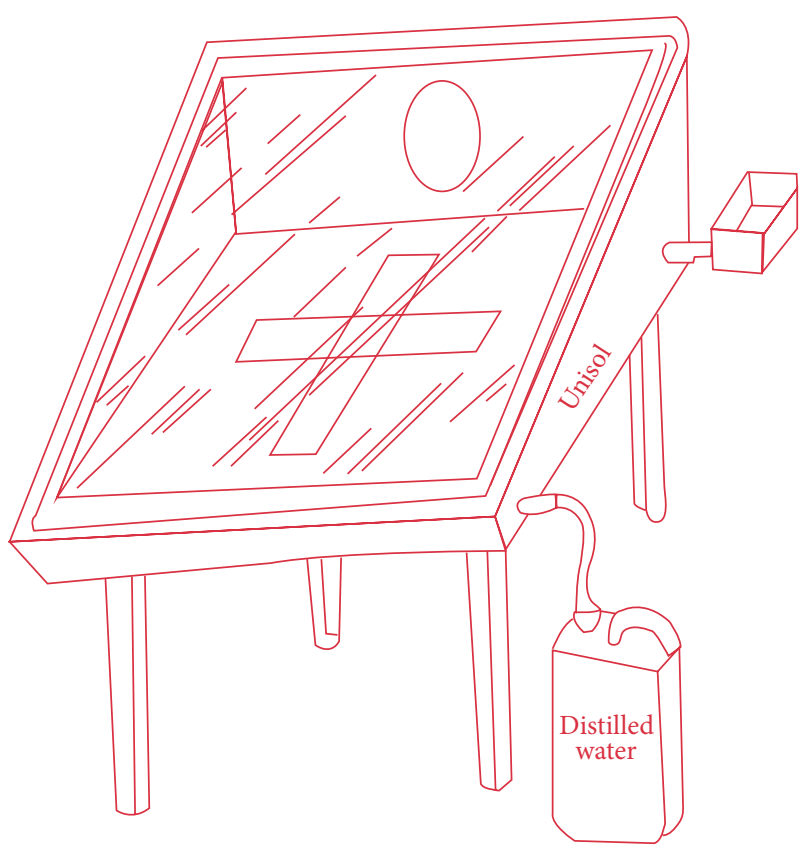

Figure 3: Solar still (courtesy: Unisol Company), http://www.unisolsolar.com/solardistillwaterplant.htm.

shown strong interest in such solar chimney power systems. Moreover, solar chimney is a promising large-scale power technology that absorbs direct and diffused solar radiation and produces power without releasing greenhouse gasses.

The concept of combination of solar chimney and seawater desalination was proposed by B. A. Kashiwa and C. B. Kashiwa [5] in 2008 for the first time. They introduced a theoretical basis for the feasibility of the solar cyclone, suggesting that an experimental study of the separation device would be worthwhile. Akbarzadeh et al. [6] suggested the utilization of a solar pond instead of collector in the solar chimney and built a small model of that. The thermal energy that is stored at the bottom of the solar pond is used in a heat exchanger to heat up the air. Kalogirou [7] did sea water desalination using renewable sources of energy. Nawayseh et al. [8], Alhazmy [9], and Zhou et al. [10] did their work in getting water production by humidification and dehumidification of sea water. At first Niroomand and Amidpour [11] integrated solar chimney for power generation and seawater desalination.

Khoo and Lee [12] developed the complete solar desalination system (Figure 4) consisting of solar collector, chimney, desalination system, and passive condenser system. The air inside the solar collector is heated up as the solar radiation strikes the solar collector. Hence, the hot air moves from the solar collector to the chimney and rises to the top due to stack effect. Inside the chimney, a sprinkler (mistifier) sprays a fine mist of saline water downwards. The hot air rising up the chimney would then transfer heat by convection into fine water droplets, causing evaporation of the saline water. The water vapour produced will then be carried up and out of the chimney by the air flow from where it will come into contact with a passive condenser and condenses to form fresh liquid
TABLE 1: Dimensions and specifications of RAC solar collector.

\begin{tabular}{lcc}
\hline S. number & Assumption(s) & Specification(s) \\
\hline 1 & Solar irradiation & $1000 \mathrm{~W} / \mathrm{m}^{2}$ \\
2 & Collector area & $1.5 \times 0.6 \mathrm{~m}^{2}$ \\
3 & Base plate & Constant \\
& temperature & \\
4 & Absorber plate & Black painted aluminium \\
5 & material & $28^{\circ} \mathrm{C}$ \\
6 & Ambient temperature & $32^{\circ} \mathrm{C}$ \\
7 & Inlet air temperature & Applied \\
8 & Double glazing & $2 \mathrm{~m} / \mathrm{s}$ \\
9 & Wind velocity & 0.88 \\
10 & Tempered glass & 0.85 \\
11 & emissivity & $80^{\circ}$ \\
12 & Tempered glass & 8 hours per day \\
13 & transmissivity & 0.09 \\
\hline
\end{tabular}

water droplets which are collected in an external reservoir. Alvarez et al. [13] designed solar collectors using recycled aluminium cans at an affordable cost.

\section{Proposed Desalination Plant}

In the present work a recycled aluminium can collector was integrated with a solar chimney. The experimental setup mainly comprises solar collector, chimney, condenser, sprinkler system, submersible water pump, exhaust fan, solar panel for power supply, and stand. A mathematical model was developed, sensitivity analyses were conducted to optimize the system, and the design parameters obtained were then used in the dimensioning and sizing of the components for fabrication. With the understanding of complete system every subsystem operation was developed and a simplified version was described with the flowchart shown in Figure 4.

3.1. Recycled Al Can (RAC) Solar Air Collector. The collector was made up of recycled aluminium soft drink cans to be built at a low cost. The baffle plate of the collector consists of 9 circular section air flow channels each made by joining 8 recycled $\mathrm{Al}$ cans (Figures 5 and 6). Table 1 shows the specifications of the solar collector. For ensuring forced convection, an exhaust fan, which runs with solar energy, was used. Tempered glass and $\mathrm{Al}$ sheet were used at the bottom of collector to ensure more heat absorption and reflection. Optimum tilt angle of collector is obtained from Ulgen [14].

3.2. Chimney with a Bend. Chimney was circular in cross section and made with galvanized sheet (Figure 7) in order to prevent rust formation. Height of chimney (without stand) was $1.5 \mathrm{~m}$ and diameter of chimney was $0.16 \mathrm{~m}$. The bottom of the chimney was left open to ensure ease of access into the chimney during experiments. It was light in weight. A bend 

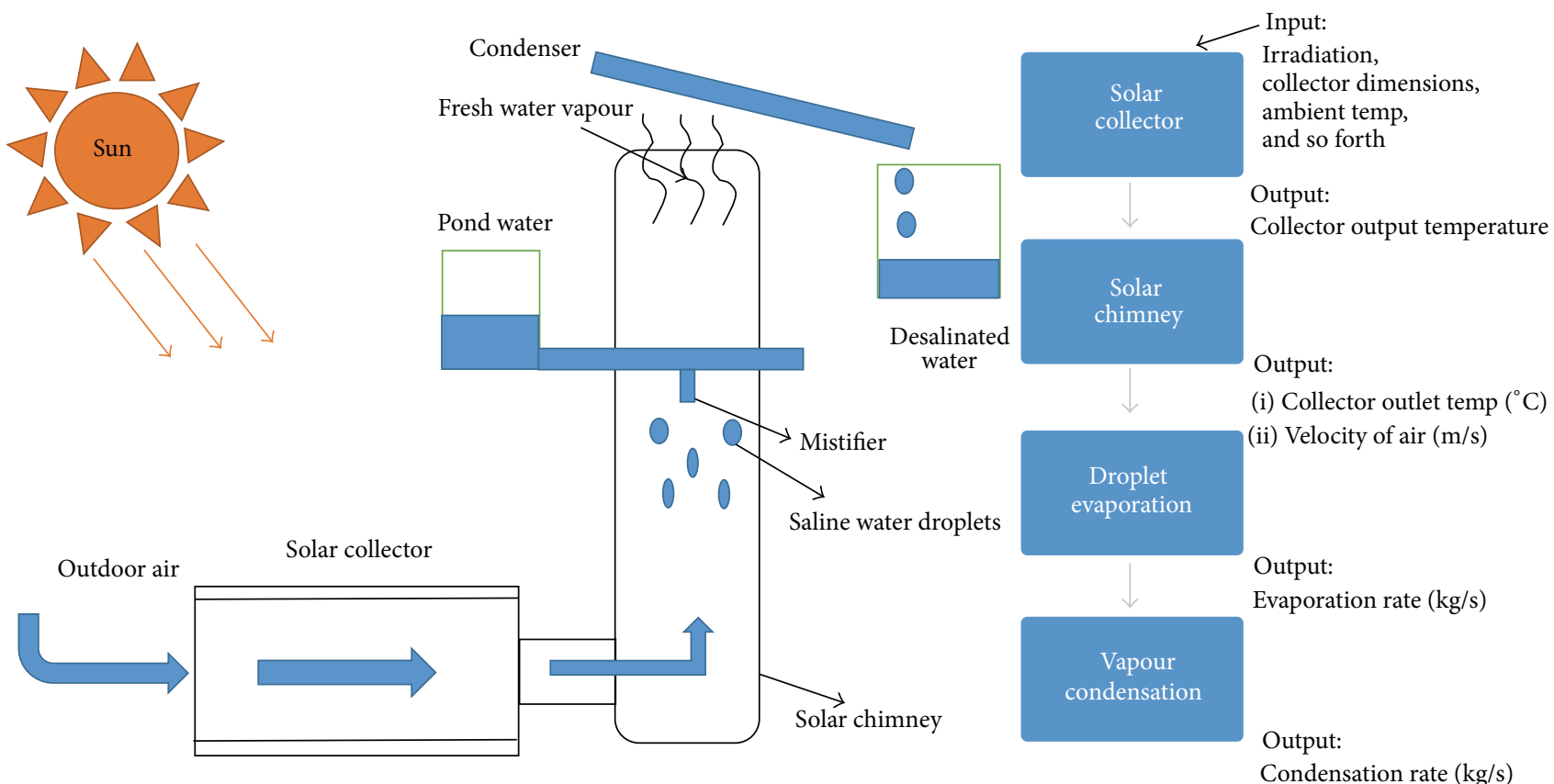

FIGURE 4: Schematic diagram and flow chart of solar desalination system.

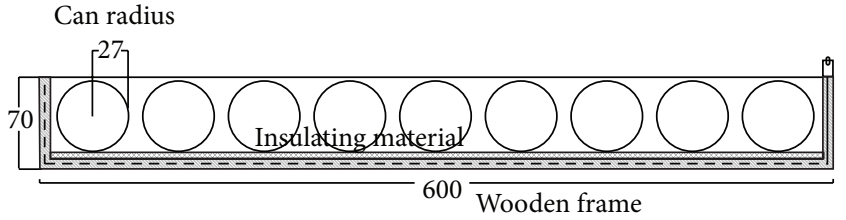

FIGURE 5: Solar collector with 9 columns of recycled aluminium cans (front view).

was provided at the end of the chimney at an angle of $45^{\circ}$ to facilitate assembly with collector. Top end of chimney was connected to the condenser.

3.3. Condenser. The condenser (Figure 8(a)) was designed with dimensions of $400 \times 450 \times 0.5 \mathrm{~mm}$ and a $30^{\circ}$ slope. A slope was provided to condenser surface for collecting water. Condenser had the provision to store ice at top.

3.4. Sprinkler System. A sprinkler (Figure 8(b)) was used for spraying water into the chimney. However, mistifier can also be used for the operation. Sprinkler would spray water. This could be evaporated by hot air which comes from chimney. The sprinkler could be placed at $1 \mathrm{~m}$ from the base of the chimney. The salt water was pumped to the sprinkler using a small submersible water pump, used in water coolers and fountains.

3.5. Construction of Desalination Plant Using Solar Chimney with RAC Collector. As seen in Figure 9, the collector and chimney were attached together using $4 \mathrm{x}$ M8 bolts. The condenser was attached at the top of the chimney. Finally, the entire system was mounted on a stand.

3.6. Experimental Conditions. The experiment was conducted for $8 \mathrm{hr}$. The values were taken at the following conditions.

Local time: 11:00 AM to 1:00 PM, on April 10, 2014.

Location: Tadepalligudem, Andhra Pradesh, India.

Latitude: $16^{\circ} 50^{\prime} 10.18^{\prime \prime}$.

Longitude: $81^{\circ} 31^{\prime} 1.81^{\prime \prime}$.

Readings for the solar panel connected are as follows: $V=$ 30 volts; $i=0.028 \mathrm{amp}$.

The following are solar parameters prevailing in the place of work. Sukhapme and Nayak [15] have given a detailed procedure for calculating solar irradiance of a system at a location:

Latitude $(\phi)=16.50 \mathrm{deg}$

Day Number $(n)=100$

Array Tilt (Slope) $(\beta)=80 \mathrm{deg}$ (but, optimal for that month is at 81 degrees) 


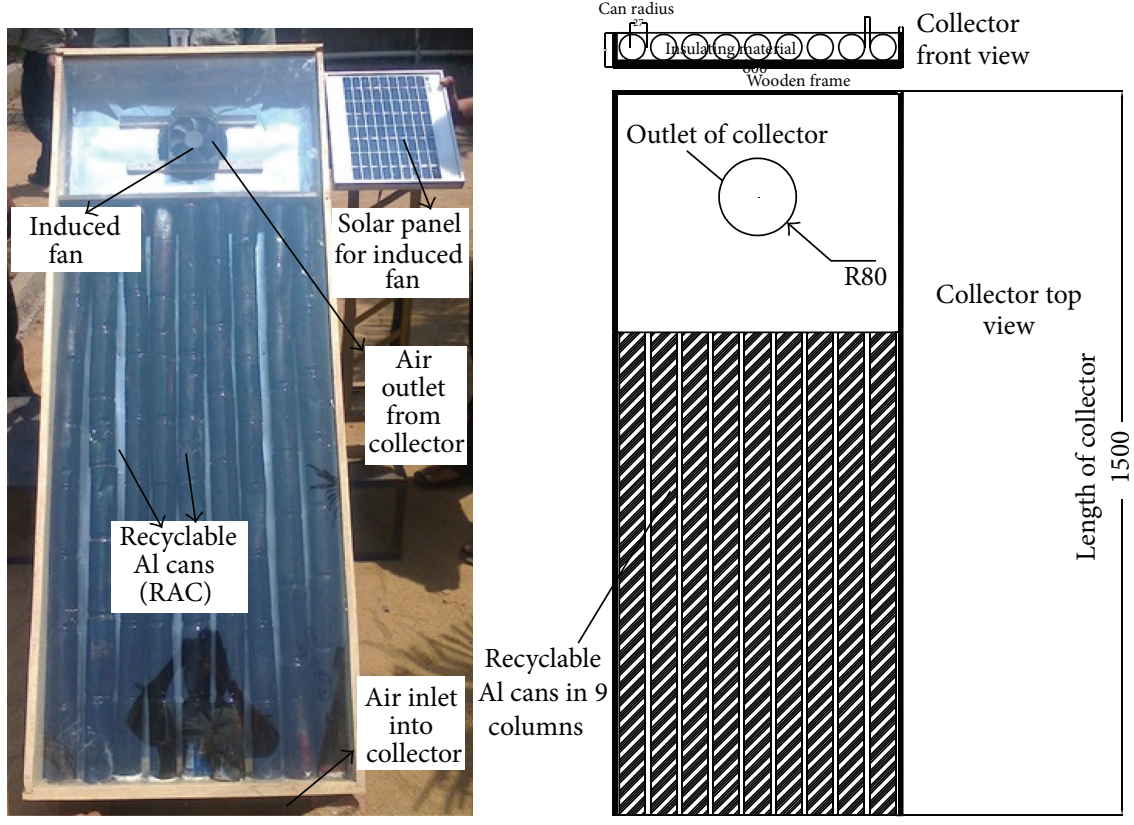

FIGURE 6: Solar collector made of recycled aluminium cans (RAC collector).

Declination angle $(\delta($ in deg $))=23.45 \sin \left[\frac{360}{365}(284+n)\right]=23.08 \mathrm{deg}$

Hour angle $(\omega)=\cos ^{-1}(-\tan \phi \cdot \tan \delta)$

Monthly avg. radiation $\left(I_{o}\right)=I_{\mathrm{sc}}\left(1+0.033 \cos \left(\frac{360 n}{365}\right)\right) \mathrm{kw} / \mathrm{m}^{2}$

Solar irradiance on a tilted surface with no atmospheric effects $\left(H_{o t}\right)$

$$
=\frac{24 I}{\pi}(\cos (\phi-\beta) \cos \delta \cdot \cos \omega+\omega \sin (\phi-\beta) \sin \delta) \mathrm{kwh} / \mathrm{m}^{2} / \text { day }
$$

Solar energy with no atmosphere $\left(H_{o}\right)=\frac{24 I}{\pi}(\cos \phi \cos \delta \cos \omega+\omega \sin \phi \sin \delta) \mathrm{kwh} / \mathrm{m}^{2} /$ day.

The above input values were submitted in (2) and irradiance was calculated as $6.39 \mathrm{kWh} / \mathrm{m}^{2}$. However, a minimal value of $1.0 \mathrm{kWh} / \mathrm{m}^{2}$ was considered in the calculations.

A mathematical model was developed, sensitivity analyses were conducted to optimize the system, and the design parameters obtained were then used in the dimensioning and sizing of the components for fabrication.

3.7. Draught Calculation. As per the chimney height draught calculation equations are

$$
\begin{aligned}
h & =353 H\left[\frac{1}{T_{1}}-\left(\left(\frac{w+1}{w}\right) \frac{1}{T}\right)\right], \\
h^{\prime} & =H\left[\left(\frac{w}{w+1}\right) \frac{T}{T_{1}}-1\right] .
\end{aligned}
$$

From the input values, $H=1.5 \mathrm{~m} ; w=200 \mathrm{~kg}$ of air $/ \mathrm{hr}$; and $T=80^{\circ} \mathrm{C}$ and $T_{1}=28^{\circ} \mathrm{C}$. Draught $(h)$ and draught height $\left(h^{\prime}\right)$ are $1.17 \times 10^{-3} \mathrm{~mm}$ of water and $3.4 \mathrm{~m}$, respectively.
3.8. Performance of RAC Solar Collector. The performance of solar air collector was calculated using the data shown in Table 2. Alvarez et al. [13] calculated RAC air solar collector thermal efficiency as the ratio of the total useful specific enthalpy flux and the total incident solar radiation flux:

$$
\eta=\frac{\int_{t_{1}}^{t_{2}} \dot{m} C_{p}}{A_{c}} \frac{\left(T_{o}-T_{i}\right) d t}{\int_{t_{1}}^{t_{2}} G \cdot d t} .
$$

3.9. Performance of Chimney. As the chimney diameter was kept constant, the velocity of the heated air flow which flows through the heat collector increases and the air volume flow rate also increases in similar proportion as the chimney height increases. The pressure difference which was caused by the air density difference between inside and outside of chimney was

$$
\Delta P=\rho_{\text {ch.in }} g H \frac{T_{\text {ch.in }}-T_{a}}{T_{a}} .
$$



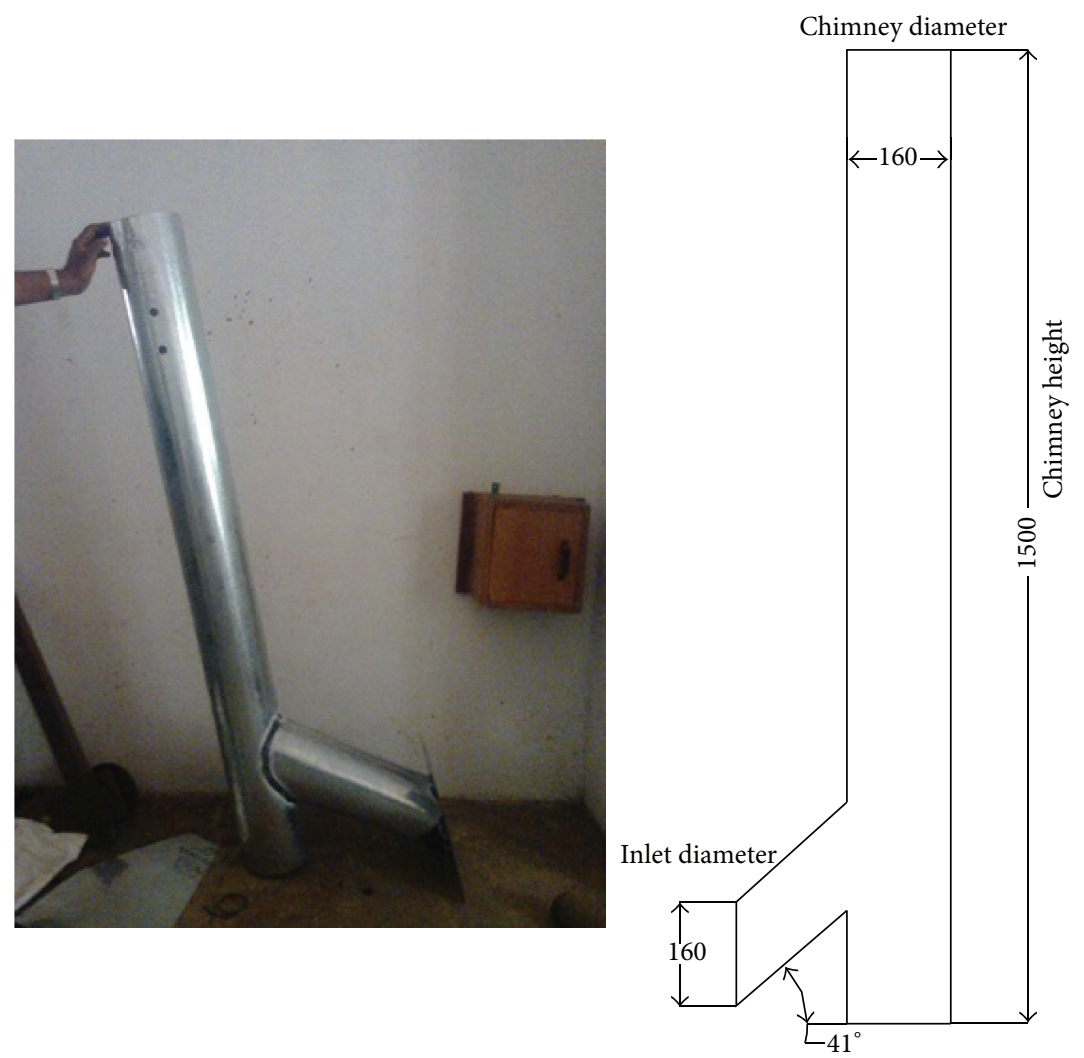

FIgURE 7: Chimney made of GI sheet and its dimensions.

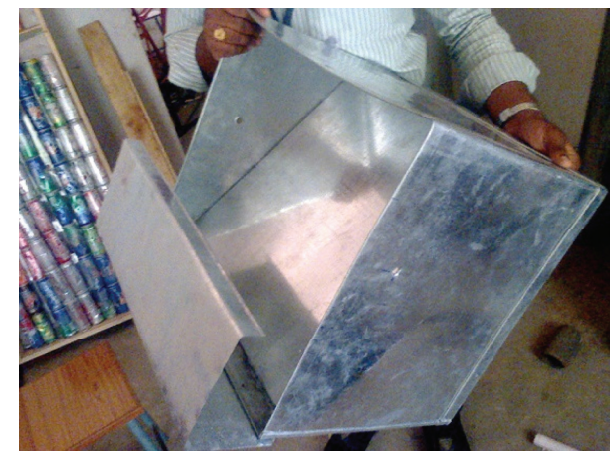

(a)

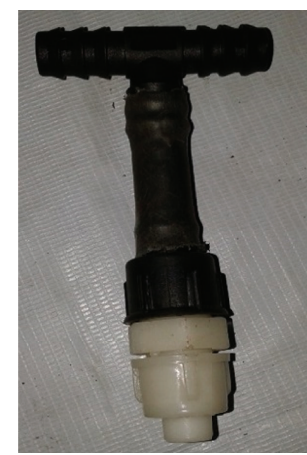

(b)

Figure 8: (a) Condenser. (b) Sprinkler.

The pressure difference was proportional to some of the factors, such as the density of the air flow at the inlet of the chimney, the temperature difference $\left(T_{\text {ch.in }}-T_{a}\right)$, and chimney height. This pressure drop would help condensation.

\section{Results and Discussion}

Before any water was sprayed into the system, the air in the system was heated through the solar collector with minimum solar irradiation of $1000 \mathrm{~W} / \mathrm{m}^{2}$ applied. The temperature distributions along the collector and chimney were recorded in Tables 3 and 4 by using laboratory thermometer and represented graphically in Figure 10.

From Figures 10(a) and 10(b), it can be seen that, with an increase in the solar radiation, the collector outlet temperature was increasing. The outlet temperature of air in the chimney is increasing continuously and this temperature could make the mist evaporate and move up. In order to determine the amount of water evaporated, the initial and final weight of the water tank were measured with the difference in weight being the amount of water evaporated by the system. The condenser walls were kept at a constant temperature of $10^{\circ} \mathrm{C}$ by using crushed ice. Initial tests were 
TABLE 2: Dimensions and specifications of RAC solar collector.

\begin{tabular}{lc}
\hline Data assumed & Value $(\mathrm{s})$ \\
\hline Length of collector & $1.5 \mathrm{~m}$ \\
Width of collector & $0.6 \mathrm{~m}$ \\
Length of absorber plate $\left(L_{1}\right)$ & $1.5 \mathrm{~m}$ \\
Width of absorber plate $\left(L_{2}\right)$ & $0.6 \mathrm{~m}$ \\
Spacing between absorber plate and bottom plate & $1.5 \mathrm{~cm}$ \\
$(L)$ & $200 \mathrm{~kg} / \mathrm{hr}$ \\
Air flow rate $(\dot{m})$ & $30^{\circ} \mathrm{C}$ \\
Air inlet temperature $\left(T_{\mathrm{fi}}\right)$ & $28^{\circ} \mathrm{C}$ \\
Ambient temperature $\left(T_{a}\right)$ & $950 \mathrm{~W} / \mathrm{m}^{2}-{ }^{\circ} \mathrm{C}$ \\
Solar flux incident on the collector face $\left(I_{T}\right)$ & 0.85 \\
Transmissivity $\left(\tau_{\alpha}\right)_{\text {avg }}$ & $6.2 \mathrm{~W} / \mathrm{m}^{2}-{ }^{\circ} \mathrm{C}$ \\
Top loss coefficient $\left(U_{t}\right)$ & $0.8 \mathrm{~W} / \mathrm{m}^{2}-{ }^{\circ} \mathrm{C}$ \\
Bottom loss coefficient $\left(U_{b}\right)$ & 0.95 \\
Emissivity top plate and bottom plate surfaces $\varepsilon_{p}$ & \\
$=\varepsilon_{b}$ &
\end{tabular}

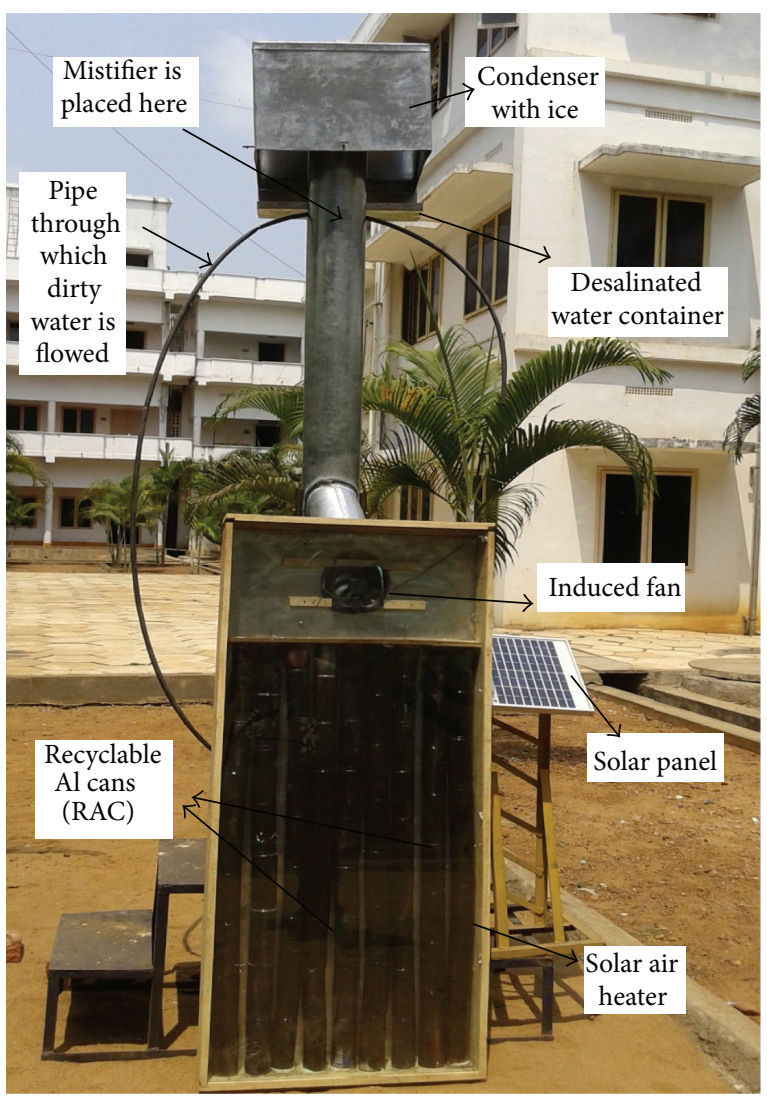

FIGURE 9: Desalination plant using a solar chimney with RAC collector.

conducted for the sprinkler system installed near the chimney outlet ( $0.5 \mathrm{~m}$ height from base of chimney) and each test ran for $1 \mathrm{hr}$. Later tests are done at second position $1 \mathrm{~m}$ from the base of chimney.

In addition, temperature measurements along the chimney were also taken to determine the temperature drop in
TABLE 3: RAC collector temperature distribution.

\begin{tabular}{lcc}
\hline Time & $\begin{array}{c}\text { Inlet temperature } \\
\text { of collector }\left({ }^{\circ} \mathrm{C}\right)\end{array}$ & $\begin{array}{c}\text { Outlet temperature } \\
\text { of collector }\left({ }^{\circ} \mathrm{C}\right)\end{array}$ \\
\hline 11:30 AM & 30 & 43 \\
11:45 AM & 31 & 49 \\
12:00 PM & 32 & 53 \\
12:15 PM & 32 & 59 \\
12:30 PM & 34 & 64 \\
1:00 PM & 35 & 74 \\
\hline
\end{tabular}

TABLE 4: Chimney temperature distribution.

\begin{tabular}{lcc}
\hline Time & $\begin{array}{c}\text { Inlet temperature } \\
\text { of chimney }\left({ }^{\circ} \mathrm{C}\right)\end{array}$ & $\begin{array}{c}\text { Outlet temperature } \\
\text { of chimney }\left({ }^{\circ} \mathrm{C}\right)\end{array}$ \\
\hline 11:30 AM & 42 & 41 \\
11:45 AM & 47 & 45 \\
12:00 PM & 52 & 51 \\
12:15 PM & 59 & 58 \\
12:30 PM & 63 & 61 \\
1:00 PM & 73 & 72 \\
\hline
\end{tabular}

TABLE 5: Temperature distribution of air in chimney at different heights (before water is sprinkled in chimney).

\begin{tabular}{lccc}
\hline \multirow{2}{*}{ Height $(\mathrm{m})$} & \multicolumn{4}{c}{ Initial temperature when no mist is sprayed $\left({ }^{\circ} \mathrm{C}\right)$} \\
& Trial 1 at 11:00 AM & Trial 2 at 01:00 PM & Average \\
\hline 2.2 & 60 & 68 & 64 \\
2.5 & 59 & 66 & 52.5 \\
2.8 & 54 & 63 & 58.5 \\
3.1 & 52 & 57 & 54.5 \\
3.4 & 49 & 56 & 52.5 \\
\hline
\end{tabular}

TABLE 6: Temperature distribution of air in chimney at different heights (after water is sprinkled in chimney).

\begin{tabular}{lccc}
\hline \multirow{2}{*}{ Height $(\mathrm{m})$} & \multicolumn{4}{c}{ Final temperature when water is sprayed $\left({ }^{\circ} \mathrm{C}\right)$} \\
& Trial 1 at 11:00 AM & Trial 2 at 01:00 PM & Average \\
\hline 2.2 & 33 & 33 & 33 \\
2.5 & 32 & 33 & 32.5 \\
2.8 & 31 & 32 & 31.5 \\
3.1 & 29 & 32 & 30.5 \\
3.4 & 29 & 31 & 30 \\
\hline
\end{tabular}

the system as water was injected into the system. Tables 5 and 6 show the air temperature distributions in chimney (before and after water was sprayed in chimney) and were represented graphically in Figure 11. Because of heat and mass transfer in the mist of water and air, the change of phase from liquid to vapour takes place. The drop in temperature with height of the chimney is due to heat losses across the chimney wall. It clearly demonstrates the need for a good insulation to be done to the chimney to minimize convection and radiation. 


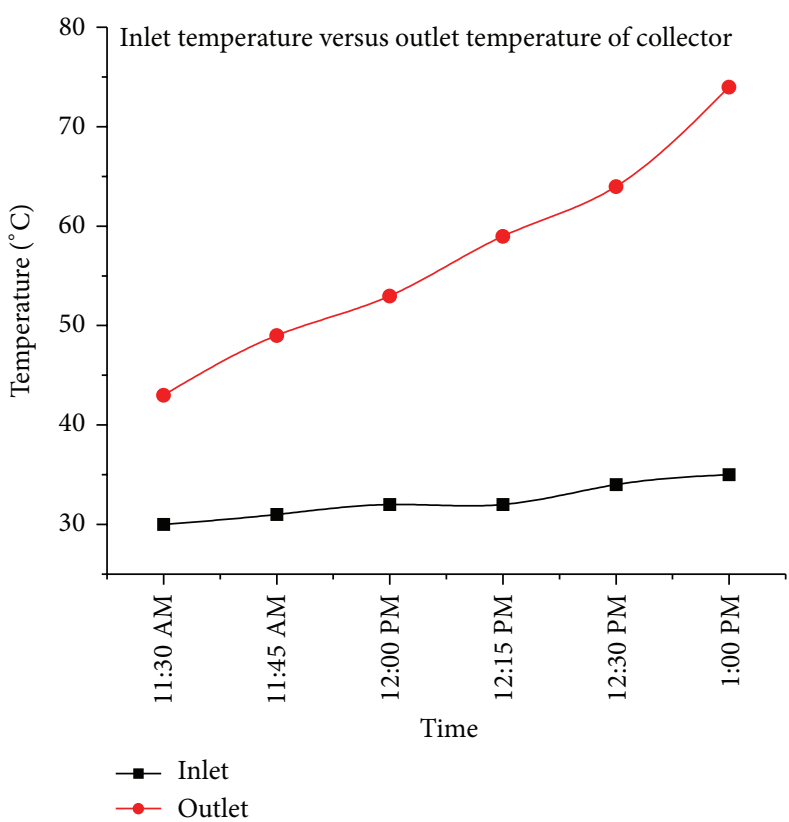

(a)

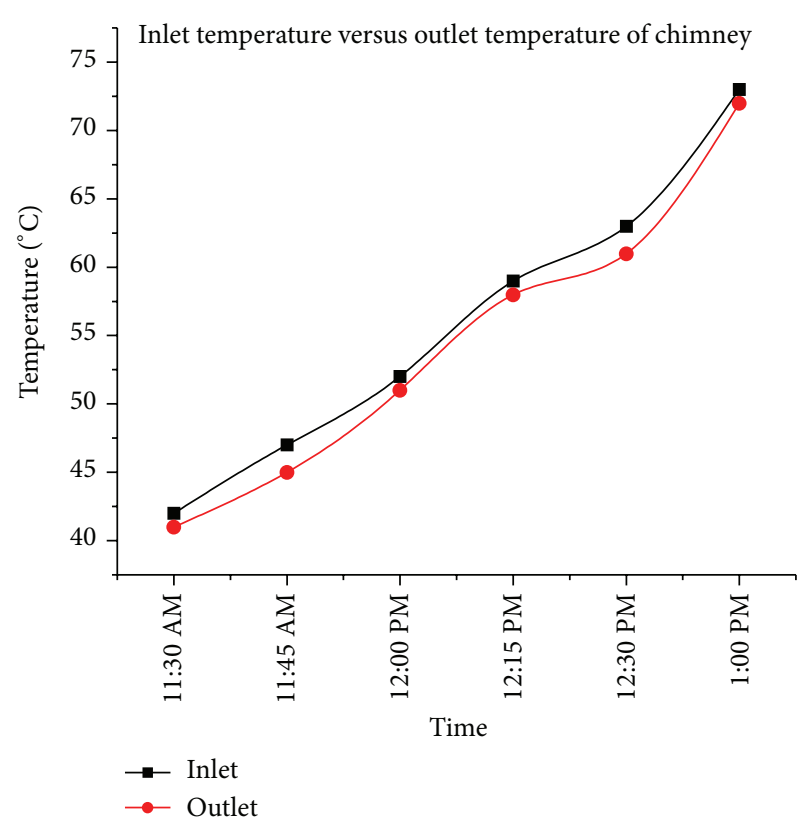

(b)

FIGURE 10: (a) Inlet and outlet temperature of collector. (b) Inlet and outlet temperatures of chimney.

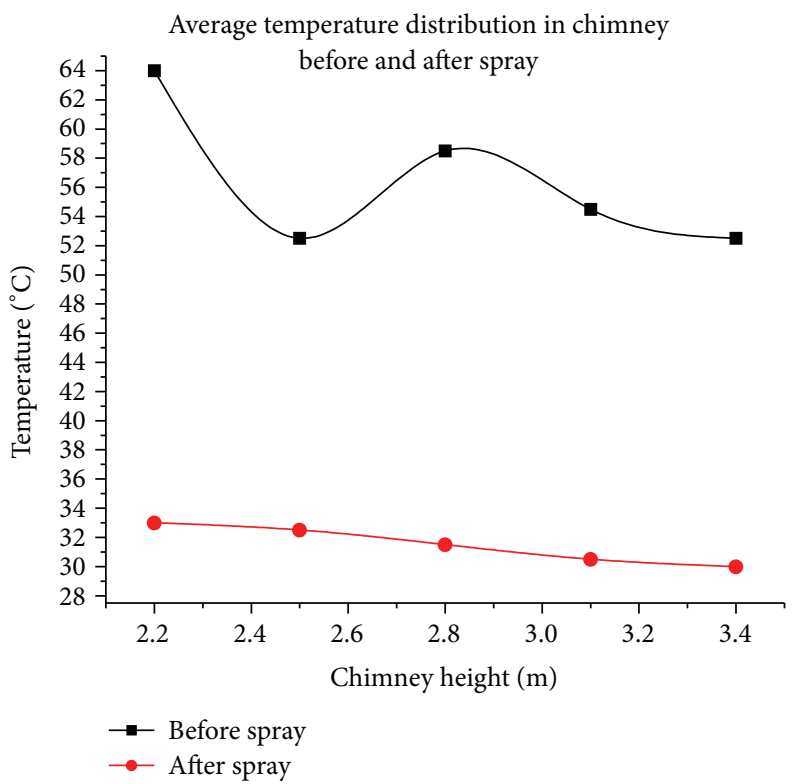

FIGURE 11: Average temperature distribution in chimney before and after spray at different height.

The air flow rate values, in chimney, measured using anemometer were tabulated in Table 7 and were represented explicitly in Figure 12. It can be seen that air flow rate without mist reaches peak at 12.00 noon, which corresponds to highest irradiance time. Accordingly the air flow rate with mist falls to minimum at around the same time as humidification increases the density of air. Air flow rate with mist curve slightly trials behind one without mist.
TABLE 7: Airflow rates in chimney.

\begin{tabular}{|c|c|c|c|}
\hline \multirow{2}{*}{ Trial } & \multirow{2}{*}{ Time } & \multicolumn{2}{|c|}{ Air flow rate in chimney (velocity $(\mathrm{m} / \mathrm{s})$ ) } \\
\hline & & Flow rate without mist & Flow rate with mist \\
\hline Trial 1 & 11:00 AM & 0.12 & 0.08 \\
\hline Trial 2 & 12:00 PM & 0.15 & 0.06 \\
\hline Trial 3 & 01:00 PM & 0.10 & 0.07 \\
\hline \multicolumn{2}{|c|}{ Average } & 0.12 & 0.07 \\
\hline
\end{tabular}

The chimney flow rate with and without mist gives the pressure drop in the chimney. The influence of chimney diameter, height, and solar radiation on the inlet water temperature and the glass cover temperature was different, respectively. Therefore, the temperature difference between water vapour and glass inner cover $\Delta T$ increased and hourly freshwater production increased in the daytime, while, at night time, the temperature difference $\Delta T$ decreased by which the freshwater production decreased.

\section{Conclusions}

The daily utilization efficiency of solar energy of the integrated system depends on the heat energy which was gained from solar energy to prepare freshwater. The primary goal of the project was achieved through the feasible solar chimney for water desalination. With the specified design parameters at a minimum solar irradiation of $1000 \mathrm{~W} / \mathrm{m}^{2}$, experimental testing was done on the prototype system, the middle of the chimney being the optimum sprinkler height capable of condensing and collecting $2.3 \mathrm{~L}$ of water by evaporating $3.77 \mathrm{~L}$ with the $3.4 \mathrm{~m}$ height of entire setup. The success of the system 


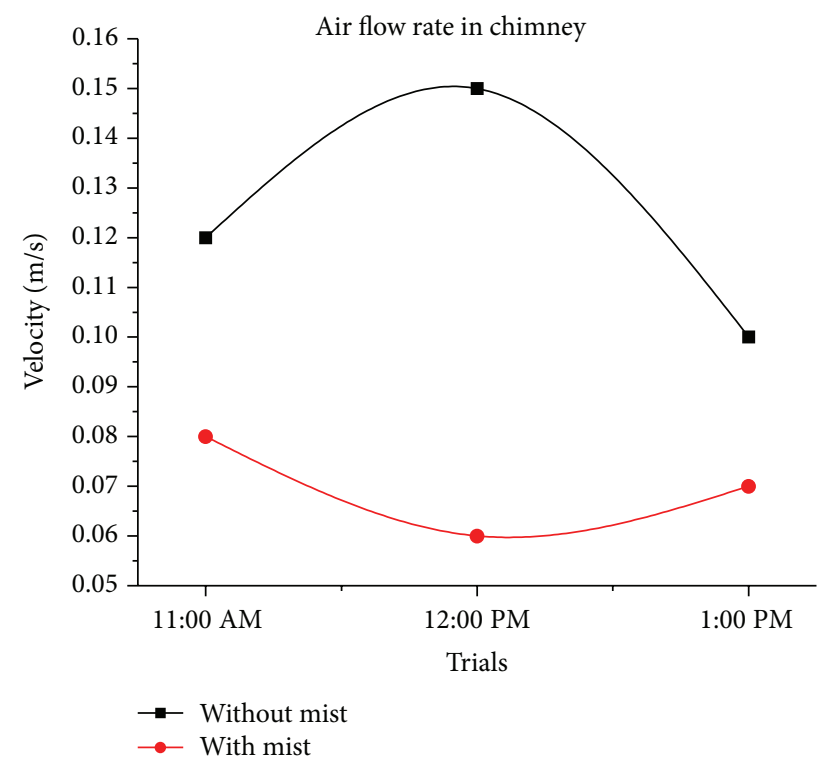

FIgURE 12: Air flow rate in chimney with and without mist.

is attributed to the unique design of RAC collector integrated with solar chimney.

\section{Nomenclature}

\author{
$h$ : Draught (mm of water) \\ $w$ : Weight of air $(\mathrm{kg} / \mathrm{kg}$ of fuel $)$ \\ T: $\quad$ Average absolute temperatures of chimney \\ gasses $\left({ }^{\circ} \mathrm{C}\right)$ \\ $T_{1}$ : Absolute temperature of air outside the \\ chimney $\left({ }^{\circ} \mathrm{C}\right)$ \\ $H$ : Height of chimney above the grate level (m) \\ $h^{\prime}$ : Draught height of hot gasses (m) \\ $A_{c}: \quad$ Collector area $\left(\mathrm{m}^{2}\right)$ \\ $G: \quad$ Incident solar radiation $\left(\mathrm{W} / \mathrm{m}^{2}\right)$ \\ $\eta$ : Thermal efficiency of the collector \\ (dimensionless) \\ $C_{p}: \quad$ Specific heat $(\mathrm{J} / \mathrm{kg} \mathrm{K})$ \\ $t$ : Time (s) \\ $T_{o}$ : $\quad$ Mean outlet temperature of the collector $\left({ }^{\circ} \mathrm{C}\right)$ \\ $T_{i}$ : $\quad$ Mean inlet temperature of the collector $\left({ }^{\circ} \mathrm{C}\right)$ \\ $\dot{m}$ : Mass flow rate $(\mathrm{kg} / \mathrm{s})$ \\ $\Delta P: \quad$ Pressure difference in chimney \\ $\rho_{\text {ch.in }}$ : Specific density of gasses in chimney \\ g: $\quad$ Gravity of earth \\ $T_{\text {ch.in }}$ : Inlet temperature of chimney $\left({ }^{\circ} \mathrm{C}\right)$ \\ $T_{a}$ : Ambient temperature around chimney $\left({ }^{\circ} \mathrm{C}\right)$ \\ $\Delta T: \quad$ Temperature difference between pond water \\ and glass inner cover $\left({ }^{\circ} \mathrm{C}\right)$.
}

\section{Disclosure}

The authors further certify that proper citations to the previously reported work have been given and no data/tables/figures have been quoted verbatim from other publications without giving due acknowledgment and without the permission of the authors.

\section{Competing Interests}

The authors declare that there is no conflict of interests regarding the publication of this paper.

\section{Acknowledgments}

The first author thankfully acknowledges the support and cooperation provided by Project Associates G. Sandeep, A. V. Manohar, R. Gopi Chowdary, and K. Satish Reddy of Sasi Institute of Technology and Engineering, Tadepalligudem, West Godavari District, Andhra Pradesh.

\section{References}

[1] B. H. Khan, Non-Conventional Energy Sources, Tata Mc-Graw Hill, New York, NY, USA, 2nd edition, 2008.

[2] S. Rajesh and G. Suresh, "Contemporary prosthetic borewell rescue system," in Proceedings of the International Conference on Emerging Trends in Mechanical Science (ICEMS '15), vol. 2, pp. 138-142, Hyderabad, India, December 2015.

[3] H. Pastohr, O. Kornadt, and K. Gürlebeck, "Numerical and analytical calculations of the temperature and flow field in the upwind power plant," International Journal of Energy Research, vol. 28, no. 6, pp. 495-510, 2004.

[4] W. Haaf, "Solar chimneys, part II: preliminary test results from the Manzanares Pilot Plant," International Journal of Solar Energy, vol. 2, no. 2, pp. 141-161, 1984.

[5] B. A. Kashiwa and C. B. Kashiwa, "The solar cyclone: a solar chimney for harvesting atmospheric water," Energy, vol. 33, no. 2, pp. 331-339, 2008.

[6] A. Akbarzadeh, P. Johnson, and R. Singh, "Examining potential benefits of combining a chimney with a salinity gradient solar pond for production of power in salt affected areas," Solar Energy, vol. 83, no. 8, pp. 1345-1359, 2009.

[7] S. A. Kalogirou, "Seawater desalination using renewable energy sources," Progress in Energy and Combustion Science, vol. 31, no. 3, pp. 242-281, 2005.

[8] N. K. Nawayseh, M. M. Farid, S. Al-Hallaj, and A. R. AlTimimi, "Solar desalination based on humidification process: I. Evaluating the heat and mass transfer coefficients," Energy Conversion and Management, vol. 40, no. 13, pp. 1423-1439, 1999.

[9] M. M. Alhazmy, "Minimum work requirement for water production in humidification-dehumidification desalination cycle," Desalination, vol. 214, no. 1-3, pp. 102-111, 2007.

[10] X. Zhou, B. Xiao, W. Liu, X. Guo, J. Yang, and J. Fan, "Comparison of classical solar chimney power system and combined solar chimney system for power generation and seawater desalination," Desalination, vol. 250, no. 1, pp. 249-256, 2010.

[11] N. Niroomand and M. Amidpour, "New combination of solar chimney for power generation and seawater desalination," Desalination and Water Treatment, vol. 51, no. 40-42, pp. 74017411, 2013.

[12] K. A. Khoo and H.-W. Lee, Solar Chimney for Desalination, Project 1061, School of Mechanical Engineering, The University of Adelide, Adelide, Australia, 2008. 
[13] G. Alvarez, J. Arce, L. Lira, and M. R. Heras, "Thermal performance of an air solar collector with an absorber plate made of recyclable aluminum cans," Solar Energy, vol. 77, no. 1, pp. 107-113, 2004.

[14] K. Ulgen, “Optimum tilt angle for solar collectors," Energy Sources Part A: Recovery, Utilization, and Environmental Effects, vol. 28, no. 13, pp. 1171-1180, 2006.

[15] P. S. Sukhapme and Nayak, Solar Energy, Tata McGraw-Hill, New Delhi, India, 2nd edition, 2008. 

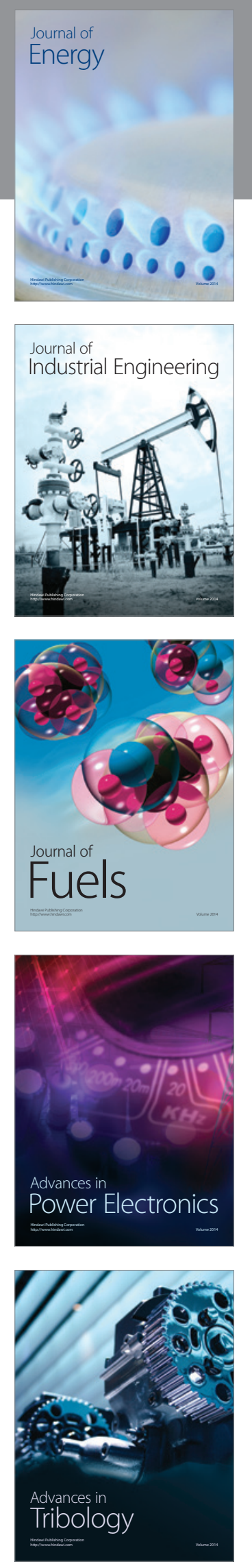
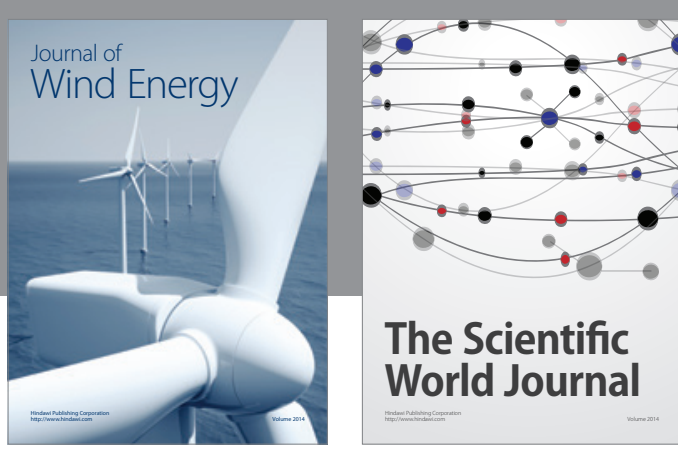

The Scientific World Journal
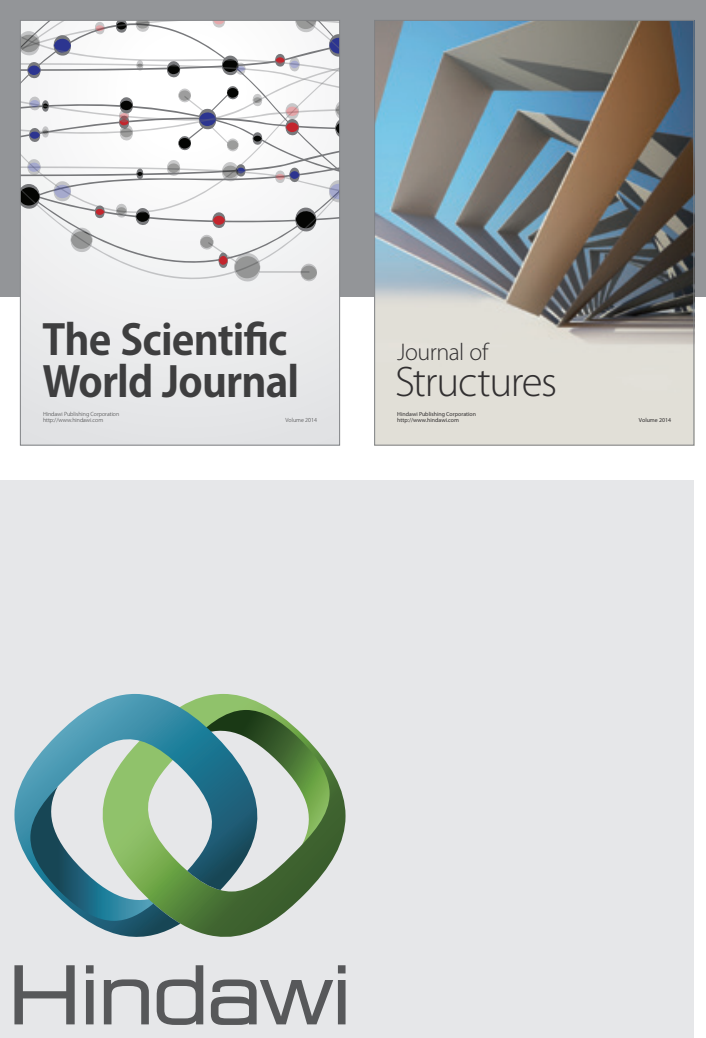

Submit your manuscripts at

http://www.hindawi.com
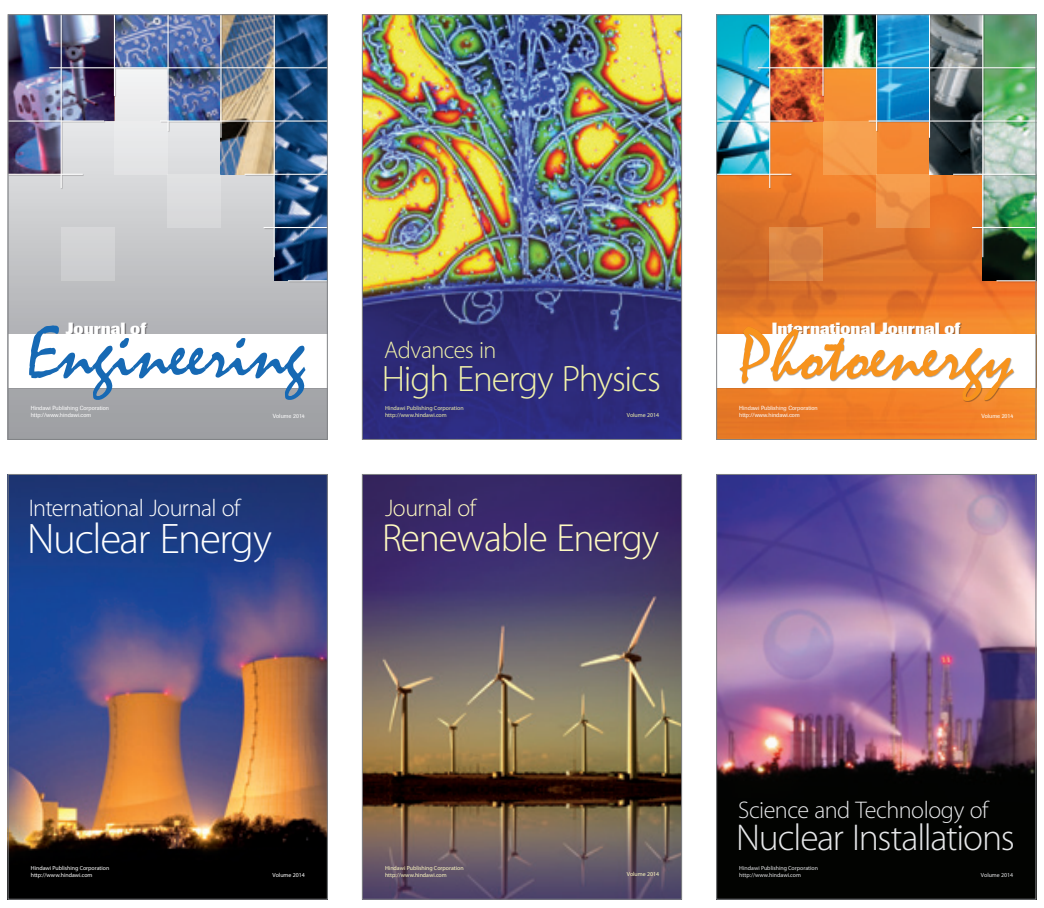
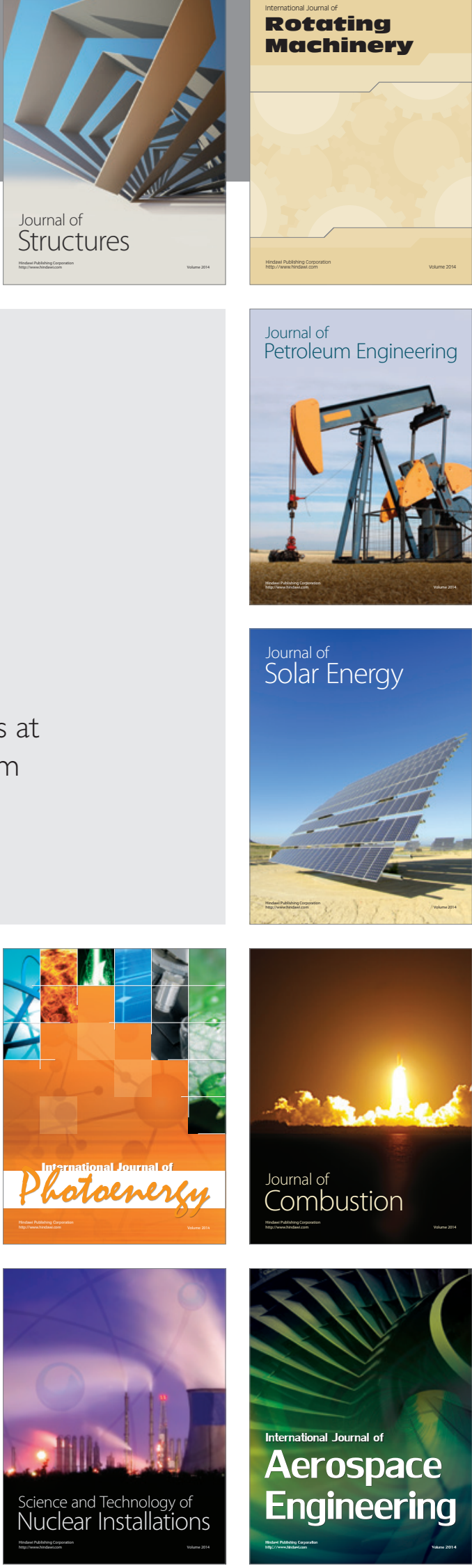